\title{
Technological Pedagogical and Content Knowledge of Biology Prospective Teachers
}

\author{
${ }^{\square}$ Evi Suryawati, Mariani Natalina Linggasari, Arnentis
}

DOI: 10.15294/biosaintifika.v9i3.11270

Biology Education, Faculty of Teacher Training and Education, Universitas Riau, Indonesia

\section{History Article}

Received 27 September 2017 Approved 5 November 2017

Published 31 December 2017

\section{Keywords}

Indonesian qualification framework; Prospective teachers; Technological pedagogical and content knowledge

\begin{abstract}
This research was conducted for analyzing Technological Pedagogical and Content Knowledge (TPACK) of biology prospective teachers in Riau Province. The study was carried out to fulfill Indonesian Government's policy on Indonesian Qualification Framework (IQF) 6-Level. This development research aimed to analyze, design and develop a model to enhance the competency and competitiveness of Education College graduates to meet their professional, social and industrial needs. This paper discussed a preliminary study of the developed models for strenghtening the prospective teachers from Biology Education Departement, conducted through a survey of 243 students from four different colleges of education in Riau Province. The data were collected through a test and interview. The instruments used contained seven variables of knowledge, namely Technology, Paedagogy, Content, Technological Paedagogy, Technological Content, Technological knowledge and TPACK. The instruments was improved through their validity and reliability test. The TPACK performance of Prospective Biology teachers seemed low. Based on the need analysis two products will be generated. First, a lesson design and the second was a work books. This study had an implications for increasing the competence of biology education graduates. The lesson design and competency test instruments could be used for College of Biology Education and teacher professional education in developing competency test for selection system. The TPACK workbook could be used as teacher enrichment in sustainable profession development such as classroom action research, learning innovation contest, and science teacher olympiad.
\end{abstract}

\section{How to Cite}

Suryawati, E., Linggasari, M. N., \& Arnentis. (2017). Technological Pedagogical and Content Knowledge of Biology Prospective Teachers. Biosaintifika: Journal of Biology \& Biology Education, 9(3), 498-505.

(C) 2017 Universitas Negeri Semarang $\square$ Correspondence Author:

Kampus Bina Widya, Simpang Baru, Tampan, Kota Pekanbaru, Riau 28293

E-mail: evi.suryawati@lecturer.unri.ac.id
p-ISSN 2085-191X e-ISSN 2338-7610 


\section{INTRODUCTION}

The Government regulation of the Republic Indonesia number 19/2005 concercing the National Education Standard, and the Government regulation number 32/2013 concerning the Amandement of Education National Standard paragraph 1 , article 8 explicitely states that teachers and educational practitioners should meet the criteria and educational eligibility of both inservice training and on the job training.Teachers are professional educators whose main duty is to educate, teach, supervise, direct, train, assess and evaluate pupils in early educational level of formal education, primary education and secondary education. Professional teachers will produce good learning process and good quality education in an effort to create smart and competitive citizens, i.e. ones who believe in the one supreme God, with good attitude and behavior, being healthy, knowledgeable, smart, creative, independent, democratic and responsible citizens. To become professional teachers, they should possess knowledge to develop the competent aspects they should have. Based on the government regulation number 14/2005 on Teachers and University Lecturers, it is stated that teacher competence includes pedagogical, professional, social and personal competences. These competencies are to be mastered by candidate teachers through their Teacher Professional Education Program (PPG).

Colleges of Education (LPTK) is a higher education institution that manage undergraduate and postgraduate educations and professions, focusing on mastering educational disciplines based on Indonesian Qualification Framework (IQF) that prepares students to become candidate teachers who meet the educational needs. Limited human resources causes the implementation of Competence-Based-Curriculum (CBC) to achieve the Education National Standard were encountered by various constraints. According to the director of Directorate General for Higher Education (2008) curriculum development should lead to the achievement of competencies already set forth with accurate analysis that matches the the competency of a study program in higher education. The development of Competence-Based-Curriculum (CBC) of IQF is done to develop the mentality of educators in creating good quality human resources on the basis of their qualifications. This will lead to the international recognition towards the quality of competeive human resources. IQF also encourages the building of the country education profile with comprehensive data.
Based on the above conditions, effort of developing the quality and teachers professionalism is badly needed. This development can be made through developing the knowledge that teachers should, have and support their profession, one of than is strengthening Technological Pedagogical and Content Knowledge (TPACK). TPACK is a framework of knowledge that shows the relationships of three kinds of knowledge teachers must master; namely, technology, pedagogy, and content (the content of learning materials). Teachers should master TPACK in order to be able to design effective learning programs. TPACK was originally developed by Mishra and Matthew J Koehler and then was developed by Lee Schulman on Pedagogical Content Knowledge (PCK) (Abbitt, 2011). The mastery of technology becomes very important in creating unlimited access to the global community and opening new way for self-development and solve the problems in learning.

The challenge of becoming a professional teacher and, the necessary competencies can not stand alone, but they must be aligned and balancing each others, so that teachers can implement an effective and efficient learning. The goal of teacher professionalism is to create a good and effective learning for students. Good learning is characterized by how students understand the content or material taught by the teacher. This is of where the teacher has an important role in designing a good learning strategy and will have a positive impact for students. Teachers are expected to actualize the knowledge and capabilities for preparing this strategy. One form of knowledge framework that teachers must have in order to be actualized in learning is Technological Pedagogical and Content Knowledge (TPACK). One form of TPACK application in learning is the use of technology by teachers in certain subject matters. The integration of technology in learning is considered important in response to the challenges of globalization era marked by the rapid development of information and communication technology. Technology can help teachers in developing their professionals, The presence of the internet can encourage, teachers look for the latest issues on education, learning strategies and the development of science. Technology can also help teachers in teaching, technology can be used as a tutor or demonstration tool. (Koh, 2013) shows the use of animation media with TPACK framework improving cognitive, affective and psychomotor learning achievement in science learning.

The challenge for educational bachelor 
graduates is to improve their competence in order to compete globally. LPTK as an academic and professional education organizer need to conduct study related to improving the quality of education. One of them is by developing IQFbased learning program and TPACK framework. College of education graduates, especially Biology, has the capability in accordance with generic description of Level 6 and 7 on IQF (KKNI) ready to compete to face global challenge. Based on the background of the problem, this study aims to analyze the potential and to map the mastery of content, pedagogy, and technology of Biology education undergraduates students in Riau Province. The results of the study will be used as the basis for the development of learning programs to meet the learning achievements in preparing qualified and competitive graduates.

\section{METHODS}

This research was a descriptive study. Using Cross Sectional Survey method. The instruments used to gather the data were a test, and interview. Participants consisted of 243 preservice teachers from 4 College of Education within Riau province: University of Riau (UR), University of Lancang Kuning (UNILAK), Islamic University of Riau (UIR) and University of Pasir Pengaraian (UPP). The test was taken from the national written test for Teachers Professional Education which was developed accordingly. This competency test consisted of 60 items in the form of multiple choices with 4 options. The test form can be seen in Table 1.

Table 1. The Total of Respondents of Competency Test for Biology Prospective Teachers

\begin{tabular}{lc}
\hline Program/University & $\begin{array}{c}\text { Total of } \\
\text { Respondents }\end{array}$ \\
\hline $\begin{array}{l}\text { Biology Teachers Professional } \\
\text { Universitas Riau }\end{array}$ & 17 \\
$\begin{array}{l}\text { Undergraduate Program (S1) } \\
\text { Universitas Riau }\end{array}$ & 41 \\
$\begin{array}{l}\text { Undergraduate Program (S1) } \\
\text { Universitas Islam Riau }\end{array}$ & 99 \\
Undergraduate Program (S1) & 38 \\
$\begin{array}{l}\text { Universitas Lancang Kuning } \\
\text { Undergraduate Program (S1) }\end{array}$ & 48 \\
Universitas Pasir Pengaraian & 243 \\
\hline Total & \\
\hline
\end{tabular}

The biology competency test based on TPACK was shown in Table 2. Table 2 showed that biology competency test include 60 items which were constructed from essential indicators for biology teacher competency test of senior high school. The items of this competency test came after an analysis in order to know the realibilty of the items. The reliability of the competency test was determined by a discriminatory index, difficulty index and Kuder Richardson 20. The item analysis included the degree of difficulty (0.34$0.92)$, and the distinguishing power (0.46-0.74). Reliability test obtained 0.68 processed with the help of SPSS for Window version 18 (Riduwan \& Sunarto, 2007; Nitko, 2004). Based on the trial results the items revised, the revised item then used on 243 of test participants. Descriptive analysis was performed to the test results of mastery of materials, pedagogy and technology.

\section{RESULTS AND DISCUSSION}

\section{Participants' profile}

The participants profile of Biology Education in four College of Education (LPTKs) within Riau Province was follows. Respondents were chosen based on some considerations. The sample for the PPG students of Riau University was taken using Total Sampling technique because the number of students was relatively small (17 students). Whereas the sample for the undergraduate students (S1) was prioritized on the eight semester students who had experienced in attending various lectures either in theoretical subjects or in practical ones such as Micro Teaching and Teaching Practice. Therefore, the proportion of the size of the sample for each university was no more than $50 \%$ from the total population. Profile of respondents based on the mastery of information technology described in Table 3. Utilization of information technology has been implemented in the subjects.

Table 3 showed the use of computer application in the teaching in learning process was still low, particularly image processing. The Information about the use of information technology was used as an idea to strengthen TPACk model for biology prospective. On the basis of the collected data, the profile of the students who became the respondents in this study was presented in Table 3 . Most of the respondents took a computer course on Microsoft Office especially Microsoft Word and only few of them used to attend Adobe Photoshop course, Corel Draw and Auto Cad. A large number of respondents have attended an English course, others used to attend other language courses such as German, a course in Music and a course in Marine Science. 
Evi Suryawati et al. / Biosaintifika 9 (3) (2017) 498-505

Table 2. The item models of Biology Competency Test based on TPACK Components

\begin{tabular}{|c|c|c|c|}
\hline Basic Competencies & Essential Indicators & $\begin{array}{l}\text { Components of } \\
\text { TPACK }\end{array}$ & $\begin{array}{l}\text { Total of } \\
\text { items }\end{array}$ \\
\hline $\begin{array}{l}\text { Understanding scien- } \\
\text { tific work principle }\end{array}$ & $\begin{array}{l}\text { Planning investigations on Biology by us- } \\
\text { ing scientific methods } \\
\text { Using scientific methods to overcome prob- } \\
\text { lems on Biology } \\
\text { Presenting research findings verbally or non- } \\
\text { verbally } \\
\text { Making and using laboratory equipments }\end{array}$ & $\begin{array}{l}\text { CK }(1 \text { item }) \\
\text { TK }(1 \text { item }) \\
\text { PK }(3 \text { items }) \\
\text { TPK }(1 \text { item }) \\
\text { TPACK }(1 \text { item })\end{array}$ & 7 items \\
\hline $\begin{array}{l}\text { Understanding learn- } \\
\text { ing materials on Biol- } \\
\text { ogy for Senior High } \\
\text { School }\end{array}$ & $\begin{array}{l}\text { Understanding the basic concept of teach- } \\
\text { ing materials on virus, bacteria, protista } \\
\text { and fungus } \\
\text { Understanding the basic concept of teching } \\
\text { materials on virus, bacteria, protista and } \\
\text { fungus } \\
\text { Understanding the basic concept of teach- } \\
\text { ing materials on the structure of of plants } \\
\text { and animals cell functions } \\
\text { The structure of plants and animals cell } \\
\text { functions, and cell transportation mecha- } \\
\text { nism } \\
\text { The structure of plants/vertebrata animals } \\
\text { cell functions, movement system/ blood } \\
\text { circulation } \\
\text { Understanding the basic concept of diges- } \\
\text { tion/breathing system, excretion system, } \\
\text { excretion system/body endurance, and } \\
\text { reproduction system } \\
\text { Understanding the basic concept of teach- } \\
\text { ing materials on the growth and develop- } \\
\text { ment of plants, metabolism, the structure } \\
\text { of the function of genetic materials and } \\
\text { heredity principles } \\
\text { Understanding the basic concept of teach- } \\
\text { ing materials on mutation, evolution and } \\
\text { biotechnology. }\end{array}$ & $\begin{array}{l}\text { CK (10 items) } \\
\text { TK (2 items) } \\
\text { TCK (4 items) } \\
\text { PCK (3 items) } \\
\text { TPACK (2 items) }\end{array}$ & 21 items \\
\hline $\begin{array}{l}\text { Mastering the aca- } \\
\text { demic competencies } \\
\text { of Biology subject for } \\
\text { Senior High School }\end{array}$ & $\begin{array}{l}\text { Understanding the nature of Natural Sci- } \\
\text { ence Learning (Biology) }\end{array}$ & $\begin{array}{l}\text { PK (14 items) } \\
\text { TPK (5 items) } \\
\text { PCK (3 items) } \\
\text { TPACK (2 items) }\end{array}$ & 24 items \\
\hline $\begin{array}{l}\text { Understanding the } \\
\text { latest development of } \\
\text { materials in Biology }\end{array}$ & $\begin{array}{l}\text { Describing the development of materials } \\
\text { in Biology that matches the development } \\
\text { of Knowledge, Technology and Science } \\
\text { (IPTEKS) }\end{array}$ & $\begin{array}{l}\text { CK }(1 \text { item }) \\
\text { TK }(3 \text { items }) \\
\text { PK }(1 \text { item }) \\
\text { TCK }(2 \text { items }) \\
\text { TPACK }(1 \text { item })\end{array}$ & 8 items \\
\hline
\end{tabular}

Total of items 60 items

The application mostly used in teaching and learning process was Microsoft Power Point. A great number of respondents said that Microsoft Power Point was used in teaching and learning process. The application used to process pictures was among others, Adobe Photoshop, Photo scape, Windows Paint, Corel Draw, Visual Basic, and Adobe Illustrator. Furthermore, the applications normally used to analyze data are among others, Ana test and SPSS. Other applications used for the same 
Evi Suryawati et al. / Biosaintifika 9 (3) (2017) 498-505

Table 3. Application of Information Technology in learning.

\begin{tabular}{|c|c|c|c|c|c|c|c|c|c|c|c|c|}
\hline & \multicolumn{3}{|c|}{ PPG UR } & S1 UR & \multicolumn{2}{|c|}{ S1 UIR } & \multicolumn{2}{|c|}{$\begin{array}{c}\text { S1 } \\
\text { UNILAK }\end{array}$} & \multicolumn{2}{|c|}{ S1 UPP } & \multicolumn{2}{|c|}{ Total (\%) } \\
\hline \multicolumn{13}{|l|}{ Sex } \\
\hline Male & 3 & 17.6 & 7 & 17.1 & 12 & 12.1 & 2 & 5.3 & 7 & 14.6 & 31 & 12.8 \\
\hline Female & 14 & 82.4 & 34 & 82.9 & 87 & 87.9 & 36 & 94.7 & 41 & 85.4 & 212 & 87.2 \\
\hline \multicolumn{13}{|l|}{ Computer Courses } \\
\hline Ever & 1 & 5.9 & 12 & 29.3 & 26 & 26.3 & 9 & 23.7 & 18 & 37.5 & 66 & 27.2 \\
\hline Never & 16 & 94.1 & 29 & 70.7 & 73 & 73.7 & 29 & 76.3 & 30 & 62.5 & 177 & 72.8 \\
\hline \multicolumn{13}{|l|}{ Other Courses } \\
\hline Ever & 2 & 11.8 & 12 & 29.3 & 17 & 17.2 & 4 & 10.5 & 4 & 8.3 & 39 & 16.1 \\
\hline Never & 15 & 88.2 & 29 & 70.7 & 82 & 82.8 & 34 & 89.5 & 44 & 91.7 & 204 & 83.9 \\
\hline \multicolumn{13}{|c|}{ Computer Application in Learning } \\
\hline MS. Word & 10 & 58.8 & 30 & 73.2 & 78 & 78.8 & 17 & 45.9 & 28 & 58.3 & 163 & 67.1 \\
\hline MS. Excel & 4 & 23.5 & 30 & 73.2 & 61 & 61.6 & 17 & 45.9 & 23 & 47.9 & 135 & 55.6 \\
\hline MS. PowerPoint & 15 & 88.2 & 38 & 92.7 & 88 & 88.9 & 18 & 48.6 & 42 & 87.5 & 201 & 82.7 \\
\hline Image Processing & 2 & 11.8 & 21 & 51.2 & 14 & 14.1 & 2 & 5.4 & 3 & 6.3 & 42 & 17.3 \\
\hline Processor Numbers & 0 & 0.0 & 0 & 0.0 & 1 & 1.0 & 17 & 45.9 & 2 & 4.2 & 20 & 8.2 \\
\hline Others & 6 & 35.3 & 24 & 58.5 & 27 & 27.3 & 3 & 8.1 & 8 & 16.7 & 68 & 28.0 \\
\hline
\end{tabular}

purpose are Microsoft Publishers to design learning media in the form of simple posters, leaflet, and others. Windows Movie Maker is used to edit videos that will be used as a learning media; Windows Media Player. GOM Player, and Win amp are used to play videos; Mozilla Firefox and Chrome are used as a browser for the Internet; You tube Downloader and Adobe Catcher are used as copy videos from webs especially You tube that can be used as learning media; and Macromedia Flash that is used to design multi-media learning. (Walsh et al., 2011) state that implementation digital technology Adobe ColdFusion-and Adobe Flash-based system in science learning can improve attention and achievement in science. The result (Sancar-Tokmaket al., 2014) showed that PSTs TPACK development and improvement. Moreover, they had to consider all these factors simultaneously. In addition they used technology to select and present pictures and audio to tell their stories. Based on the collected data, the students achievement profile in completing the Biology competency test based on essential indicators are presented in Table 4.

The results of the competency test described that the students ability on the 12 essential indicators was still low. The skills of planning biological investigations using scientific methods and using scientific methods to solve biological problems were low. The low score of students could be influenced by many factors, such as not yet developing students science process skills or due to scientific investigations conducted subjects of expertise / content for example on the basic biology course is still verification and not inquiry. Mastery The basic concept of teaching materials for the structure of plant and animal cells, the mechanism of cell transport, the structure of vertebrate animal tissue / tissue function, the motion / circulatory system is generally an abstract concept, requiring high analytical and thinking skills. The basic concept of the material of growth and development of plants, metabolism, the structure of the function of genetic material, the principle of heredity is the lowest concept obtained by students. This is happen because this material is a difficult material, so the lecturers need to be more creative in delivering it and use the technology. This material was also known to have many essential concepts that require reasoning and critical thinking skills to understand it. Certain genetic concepts even after learning are still not understood by the students. There is was a consensus among teachers and students that genetics is one of the most difficult units to teach and learn. The results of this study also confirm that the basic concept of teaching material of mutation, evolution, and biotechnology of students is still low. Content knowledge is an important characteristic of effective science teachers. (McConnell et al., 2013) state that 
Evi Suryawati et al. / Biosaintifika 9 (3) (2017) 498-505

Table 4. Students Profile in Completing the Biology Competency Test of TPACK

\begin{tabular}{cccccccc}
\hline $\begin{array}{c}\text { Essential } \\
\text { indicators }\end{array}$ & $\mathrm{A}$ & $\mathrm{B}$ & $\mathrm{C}$ & $\mathrm{D}$ & $\mathrm{E}$ & Average & $\mathrm{SD}$ \\
\hline 1.1. & 45.1 & 54.5 & 48.8 & 53.5 & 50.0 & 50.4 & 3.77 \\
1.2. & 44.1 & 36.6 & 31.3 & 28.9 & 39.6 & 36.1 & 6.14 \\
1.3. & 41.2 & 34.1 & 35.4 & 34.2 & 27.1 & 34.4 & 5.01 \\
1.4. & 47.1 & 68.3 & 36.9 & 36.8 & 37.5 & 45.3 & 13.56 \\
2.1. & 52.0 & 54.9 & 38.0 & 32.9 & 42.4 & 44.0 & 9.26 \\
2.2. & 69.7 & 64.1 & 50.6 & 47.4 & 44.9 & 55.4 & 10.93 \\
2.3. & 46.2 & 41.8 & 33.2 & 47.4 & 26.8 & 37.1 & 8.85 \\
2.4. & 60.5 & 62.4 & 46.9 & 48.9 & 41.1 & 51.9 & 9.15 \\
2.5. & 35.9 & 43.7 & 37.1 & 29.7 & 29.8 & 35.2 & 5.80 \\
2.6. & 37.5 & 48.8 & 38.0 & 29.6 & 27.6 & 36.3 & 8.37 \\
3.1. & 57.4 & 49.4 & 25.0 & 21.1 & 30.2 & 36.6 & 15.9 \\
4.1. & 26.5 & 52.4 & 38.9 & 38.2 & 37.5 & 38.7 & 9.22 \\
Average & 46.9 & 50.9 & 38.3 & 37.4 & 36.2 & & \\
SD & 11.73 & 10.73 & 7.40 & 9.91 & 7.78 & & \\
\hline
\end{tabular}

assessment of teacher content knowledge poses several challenges. Educators and researchers need a strategy for assessing teacher content knowledge that is efficient but authentic, offers some level of standardization, can be applied to multiple content areas, and provides insight into teachers deep understandings of science concepts, even when applied to small sample groups (Goldey et al., 2012). Biological Inquiry, in which $>50 \%$ of all incoming, first-year students enroll. The course replaced a traditional, content-driven course that relied on outdated approaches to teaching and learning. We diversified pedagogical practices by adopting guided inquiry in class and in labs, which are devoted to building authentic research skills through open-ended experiments. Students develop core biological knowledge, from the ecosystem to molecular level, and core skills through regular practice in hypothesis testing, reading primary literature, analyzing data, interpreting results, writing in disciplinary style, and working in teams. Assignments and exams require higher-order cognitive processes, and students build new knowledge and skills through investigation of real-world problems (e.g., malaria developed course structure of biological inquiry. The course structure for building students teamwork, mastering primary literature, oral presentation and communication skills through research posters. Teacher educators who plan and implement professional development designed to enhance science content knowledge must be attentive to both incoming knowledge and changes in teachers ideas. Given the importance of students per- ceptions to the understanding of the effectiveness of teaching with technology in higher education. According (Sancar-Tokmak, 2013), technology integrated teachers inservice training can enhance teacher competency, believe and self efficacy. The result showed a significance difference between the Personal Science Teacher's (PST's) science teaching efficacy beliefs before and after the Expertise Based Training (XBT) instruction.

\section{The Prototype of lesson design and workbooks}

Based on the analysis of the respondents profiles (needs assessment) and the analysis of the Biology competency test data, a learning design will be integrated in the IQF-based curriculum of undergraduate (S1) students majoring in Biology. Therefore, the materials that were expected to be integrated in some subjects are required. The next step is analyzing several subjects that can be categorized into TPACK so that IQF-basedworkbooks could be designed based on TPACK or they can strengthen TPACK as displayed in Figure 1.

The workbooks to be developed were workbooks for Science in Education (Natural Science Learning Biology) based on IQF with TPACK approach. The workbooks were very relevant to the latest issues such as the provision of professional teachers with competences. The workbooks were very useful because they contained clear and accurate competency standards based on IQF with TPACK approach for Biology study program. It was expected that the Biology candidate teachers master all the competencies 
so that they can compete with other graduates from other faculties or study programs. (Mishra \& Koehler, 2006) while addressing the complex, multifaceted, and situated nature of this knowledge. We argue, briefly, that thoughtful pedagogical uses of technology require the development of a complex, situated form of knowledge that we call Technological Pedagogical Content Knowledge (TPCK state that TPACK consists of three components: content, pedagogy, and technology. It played a key role in improving the quality of learning as the three components are closely related to each other. Pedagogy makes use of technology constructively to teach a certain material so that students are helped to understand the lesson and to solve the problems they have through making use of technology in the teaching and learning process. Technology can also be used to enrich the existing knowledge and develop new epistemology or to strengthen the old one. Loughran (2014) added that the pedagogy the teachers put into practice is expected to enable learning culture by which students can study and develop themselves through experience provided by the teacher during the teaching and learning process. Material for Mathematics Education and Natural Science based on IQF and the TPACK approach was produced. The workbooks consist of three parts, i.e. Introduction (Part1), Teachers Competencies (Part 11) and Workbooks (Part 111).

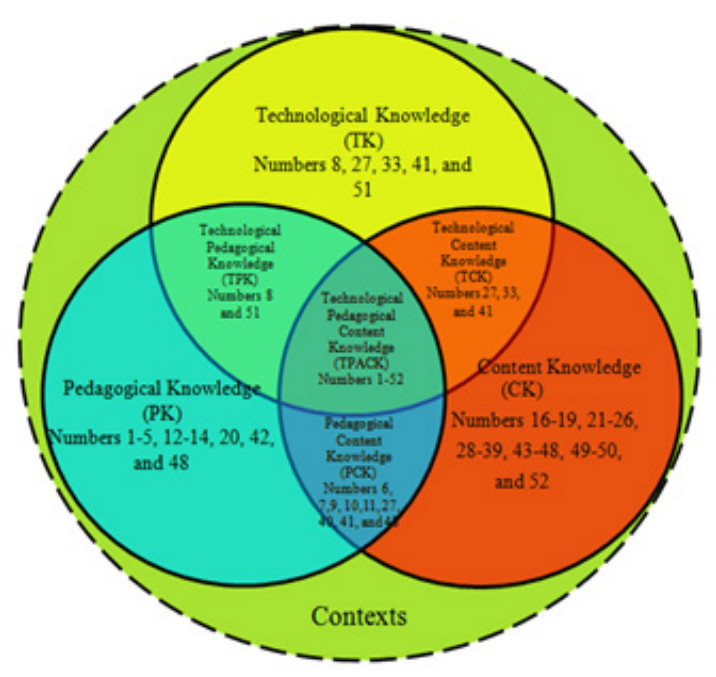

Figure 1. The relatioships between the subject course and TPACK Framework

The teaching and learning process is not only restricted to the relationship between teachers and students but a complex process that is focused on preparing students to become compe- tent persons. Ridlo and Alimah,S. (2013) stated that learning involves the interaction of lecturer, students, and learning resources. The studentcentered learning of environmental exploration may be conducted using active-and cooperativebased strategies. Therefore, teachers should support, supervise and guide students to achieve the desired competencies (Goodwin et al., 2014). (Williams, 2014) added that there are three teacher essential dimensions in the teaching and learning process; that is, (1) managing the teachers conception relating to personal identity, (2) identifying the perspective change related to the teaching and learning process, (3) negotiating complex professional relationships associated with learning. These three dimensions explain the teachers ability in understanding pedagogical components.

Overall, this study has implications for increasing the competence of biology education graduate. The lesson design and competency test instruments can be considered for College of Biology Education and teacher professional education in developing competency test for selection system. The TPACK workbook can be used as enrichment for teachers in sustainable profession development such as classroom action research, learning innovation contest, and science teacher olympiad.

\section{CONCLUSION}

The competency of the prospective teachers was still low in terms of the aspects of content and technology although it was already good enough in terms of pedagogy. Therefore, the IQF and TPACK-based-Lesson Plan and Workbooks are badly needed in order for the College of Education (LPTK) graduates to be able to improve their competencies and the ability to compete and to support the vision and missions of the Directorate General of Higher Education. LPTK especially Faculty of Education is expected to be able to produce educated people with good character, being smart, skillful and highly competitive in order to develop Indonesian citizens who possess outstanding capability and competencies in order to create prosperity, security, welfare and justice.

\section{ACKNOWLEDGEMENT}

Support for this project was funded by National Strategic Competitive Grant Directorate General of Research, Technology and Higher Education Through The Center of Research and Community Service University of Riau (No. 
543/UN.19.5.1.3/LT/2016). The ideas in this manuscript are solely generated by the authors. We would like thank to Dr. Yenita Roza, Dr. Rian Vebrianto, Dr. Riki Apriyandi Putra and everyone which help this research.

\section{REFERENCES}

Abbitt, J. T. (2011). Measuring technological pedagogical content knowledge in preservice teacher education: A review of current methods and instruments. Journal of Research on Technology in Education, 43(4), 281-300.

Goldey, E. S., Abercrombie, C. L., Ivy, T. M., Kusher, D. I., Moeller, J. F., Rayner, D. A., ... Spivey, N. W. (2012). Biological inquiry: A new course and assessment plan in response to the call to transform undergraduate biology. CBE Life Sciences Education, 11(4), 353-363.

Goodwin, A. L., Smith, L., Souto-Manning, M., Cheruvu, R., Tan, M. Y., Reed, R., \& Taveras, L. (2014). What Should Teacher Educators Know and Be Able to Do? Perspectives From Practicing Teacher Educators. Journal of Teacher Education, 65(4), 284-302.

Koh, J. H. L. (2013). A rubric for assessing teachers lesson activities with respect to TPACK for meaningful learning with ICT. Australasian Journal of Educational Technology, 29(6), 887-900.

Loughran, J. (2014). Professionally Developing as a Teacher Educator. Journal of Teacher Education, 65(4), 271-283.

McConnell, T. J., Parker, J. M., \& Eberhardt, J. (2013). Assessing Teachers Science Content Knowl- edge: A Strategy for Assessing Depth of Understanding. Journal of Science Teacher Education, 24(4), 717-743.

Mishra, P., \& Koehler, M. J. (2006). Technological pedagogical content knowledge: A framework for teacher knowledge. Teachers College Record, 108(6), 1017.

Nitko, J. A. (2004). Educational Assesment of Students. Newyork: Merril

Ridlo, S. \& Alimah, S. (2013). Competency and Conservation-Based Strategies in Biology Learning. Biosaintifika: Journal of Biology \& Biology education, 5(2), 121-129.

Ridwan \& Sunarto. (2007). Pengantar Statistika untuk Penelitian Pendidikan, Sosial, Komunikasi, dan Bisnis. Bandung: Alfabeta.

Sancar-Tokmak, H. (2013). Effects of video-supported expertise-based training (XBT) on preservice science teachers self-efficacy beliefs. Eurasia Journal of Mathematics, Science and Technology Education, 9(2), 131-141.

Sancar-Tokmak, H., Surmeli, H., \& Ozgelen, S. (2014). Preservice science teachers perceptions of their TPACK development after creating digital stories. International Journal of Environmental and Science Education, 9(3), 247-264.

Walsh, J. P., Sun, J. C. Y., \& Riconscente, M. (2011). Online teaching tool simplifies faculty use ofmultimedia and improves student interest and knowledge in science. CBE Life Sciences Education, 10(3), 298-308.

Williams, J. (2014). Teacher Educator Professional Learning in the Third Space: Implications for Identity and Practice. Journal of Teacher Education, 65(4), 315-326. 